\title{
UM PERCURSO HISTÓRICO E NOÇÕES GERAIS DA HERMENÊUTICA FILOSÓFICA DE GADAMER: UMA ANÁLISE FILOSÓFICA PARA A COMUNIDADE JURÍDICA
}

\author{
A HISTORICAL PATH AND GENERAL NOTIONS OF GADAMER'S \\ PHILOSOPHICAL HERMENEUTICS: A PHILOSOPHICAL ANALYSIS \\ FOR THE LEGAL COMMUNITY
}

Fernando de Brito Alves

Guilherme Fonseca de Oliveira

\section{RESUMO}

0 artigo apresenta uma análise etimológica do vocábulo hermenêutica e conceituações modernas a respeito dessa temética. Mostra um panorama do pensamento dos autores que mais influenciaram a proposta gadameriana em perspectiva voltada à análise da própria hermenêutica filosófica, a saber: Schleiermacher, Dilthey e Heidegger. Expõem noções gerais sobre a hermenêutica filosófica - em especial quanto às características de intersubjetividade e pragmática - que constituem o pano de fundo do pensamento gadameriano. São tecidas breves considerações sobre a tese contra-metódica de Gadamer e algumas de suas influências para o pensamento jurídico. 0 escrito se vale do método dedutivo e de revisão da bibliografia jurídica e filosófica pertinentes. Está divido em três seções: na primeira seção são explorados conceitos modernos sobre hermenêutica; na segunda seção são feitas considerações sobre os pensamentos de Schleiermacher, Dilthey e Heidegger no que importam à hermenêutica filosófica; finalmente, na terceiça seção, são expostas noções gerais sobre a hermenêutica filosófica de Gadamer e também as influências de sua posição contra-metódica no Direito. As conclusões do trabalho seguem 
no sentido de que a hermenêutica filosófica abre um horizonte de possibilidades para o pensamento jurídico, servindo como possível base para o desenvolvimento ulterior de uma hermenêutica jurídica e quiçá uma teoria da decisão judicial pautada nos pressupostos do pensamento gadameriano.

Palavras-chave: Hermenêutica filosófica. Hermenêutica jurídica. Hans-Georg Gadamer; Intersubjetividade. Pragmática.

\section{ABSTRACT}

The article presents an etymological analysis of the term hermeneutics and modern conceptualizations regarding this thematic. It shows a overview of the thinking of the authors that most influenced the Gadamerian proposal, focused on the analysis of the philosophical hermeneutics, namely: Schleiermacher, Dilthey and Heidegger. It exposes general notions about philosophical hermeneutics - especially as to the characteristics of intersubjectivity and pragmatics - that constitute the background of Gadamerian thought. Brief considerations are made on Gadamer's counter-methodical thesis and its influences on legal thinking. The writing is worth of deductive method and of revision of the pertinent legal and philosophical bibliography. It is divided into three sections: the first section explores modern concepts of hermeneutics; In the second section are exposed the thoughts of Schleiermacher, Dilthey and Heidegger, concerning to philosophical hermeneutics; Finally, in the third section, are exposed general notions about Gadamer's philosophical hermeneutics and also the influences of his counter-methodical position in Law. The conclusions of this article follow that philosophical hermeneutics opens a horizon of possibilities for legal thought, serving as a possible basis for the further development of a legal hermeneutics and perhaps a theory of judicial decision based on the assumptions of Gadamerian thought.

Keywords: Philosophical hermeneutics. Legal hermeneutics. Hans-Georg Gadamer. Intersubjectivity. Pragmatic.

\section{INTRODUÇÃo}

A hermenêutica filosófica de Gadamer tem influenciado inúmeros autores na constituição de suas respectivas propostas de hermenêutica jurídica. Em que pese a proposta gadameriana sirva ao fim de uma 
hermenêutica universal - isto é, uma hermenêutica que não se resume na constituição de uma hermenêutica especificamente jurídica, mas, sim, numa proposta de compreensão do próprio compreender -, os traços gerais dessa hermenêutica influenciaram, em âmbito internacional, jusfilósofos como Karl Larenz e Friedrich Müller e, em âmbito nacional, Lenio Luiz Streck e Eros Roberto Grau, sem prejuízo de muitos outros. Isto, pois, para esses autores, a compreensão é condição de possibilidade para a própria interpretação jurídica, razão pela qual se justifica assimilar o percurso histórico rumo à constituição da hermenêutica filosófica de Gadamer - o que primeiro se almeja neste artigo.

A hermenêutica de Gadamer é amplamente influenciada pelo chamado giro linguístico-pragmático ocorrido na filosofia em meados do século XX. A partir de uma nova concepção ontológica, de influência especial de Martin Heidegger. Esse giro, põe a linguagem e a pragmática como condição de possibilidade para compreensão do próprio mundo: 0 mundo passa a se manifestar em linguagem, a linguagem passa a ser a casa do ser. Em razão disso, uma nova perspectiva ontológica demanda uma nova hermenêutica que lhe compreenda, e é este o papel da hermenêutica filosófica. De fato, Hans-Georg Gadamer oferece uma hermenêutica totalmente nova, que leva a sério a temporalidade e a própria condição existencial do indivíduo que interpreta, porque pautada na linguagem e no diálogo.

A partir de revisão bibliográfica, valendo-se do método dedutivo, será apresentado o caminho até a constituição da hermenêutica filosófica e também noções gerais dessa proposta hermenêutica. A escolha pelo método dedutivo se deu justamente a fim de se deduzir essas noções gerais da hermenêutica gadameriana. Partindo de uma ampla gama de conceitos desenvolvidos na história da hermenêutica, são deduzidas "regras gerais" do "como" de uma hermenêutica dita propriamente gadameriana.

0 artigo será divido em três seções: na primeira seção, será exposta uma breve análise etimológica do vocábulo hermenêutica e também as principais conceituações modernas de hermenêutica, com vistas à compreensão da hermenêutica filosófica de Gadamer; na segunda seção, será exposto um percurso histórico e um panorama 
geral sobre as contribuições de três grandes teóricos que influenciaram decisivamente o pensamento de Gadamer: Schleiermacher, Dilthey e Heidegger; na última seção, serão expostas noções gerais sobre a hermenêutica filosófica de Gadamer - em especial, o que diz respeito à pragmática e a intersubjetividade inerentes à linguagem e ao diálogo - e exemplificativamente será apontada a relevância da proposta contrametódica gadameriana no Direito e as condições intersubjetivas postas pela linguagem para a hermenêutica geral (que serve também ao direito).

A pretensão de se reconstruir a história da hermenêutica filosófica não é arbitrária. Justifica-se segundo o que o próprio Gadamer, influenciado por Martin Heidegger, sustenta: o ser das coisas tem seu sentido na temporalidade e a historicidade constitui um passado ou tradição de sentido que sempre antecipa os passos - isto é, condiciona as perspectivas do intérprete. Assim, a própria compreensão da hermenêutica de Gadamer e consequentemente do sentido das hermenêuticas jurídicas por ele influenciadas pressupõe a compreensão do locus histórico da hermenêutica filosófica.

Por derradeiro, o que se tem em mente como possível contribuição para a comunidade acadêmica é a possibilidade de se apresentar a hermenêutica filosófica de Gadamer como proposta que se opõe a uma tradição de pensamento específica, principalmente ao se pautar em pressupostos pragmáticos e intersubjetivos. Dessa forma, Gadamer - seguindo os passos de Heidegger - derruba qualquer concepção de verdade absoluta e estática. E, nesse sentido, abre horizontes para uma hermenêutica jurídica extensa a partir do pensamento gadameriano (como já fez Hernández-Largo) e quiçá uma teoria da decisão judicial.

\section{UMA ANÁLISE ETIMOLÓGICA E CONCEITUAÇõES DE HERMENÊUTICA}

A princípio não há como deixar de lado uma análise etimológica da palavra hermenêutica, isto porque um trabalho que pretenda falar sobre filosofia da linguagem no direito não pode desprezar a própria palavra; não se pode deixar que, antes de se expor qualquer consideração, 
seja permitido à palavra se revelar por si. Em outras palavras, não há como desenvolver a proposta do artigo de explorar a hermenêutica filosófica gadameriana sem antes compreender a tradição de sentido que contamina a própria palavra "hermenêutica".

A palavra hermenêutica guarda relações com a ideia de compreensibilidade de sentido, ou desvelamento de sentido. A ideia de que a hermenêutica tem como objeto a compreensibilidade do sentido vem justamente da etimologia: costuma-se distinguir três orientações básicas do significado de hermenêutica: expressar (dizer, falar), expor (interpretar, explicar) e traduzir (ser intérprete). Não é difícil, no entanto, notar que as últimas duas funções poderiam ser reproduzidas pelo mesmo verbo, pois o traduzir, isto é, a transposição de sons estranhos em algo familiar, em certo sentido equipara-se a interpretar. Dessa forma, restam apenas dois significados: expressar e interpretar. No entanto, mesmo aqui é possível constatar um denominador comum: ao "expressar", de certa forma o espírito externaliza os seus conteúdos, enquanto "interpretar" procura explorar a expressão externada em seu conteúdo interno. Sendo assim, parece possível dizer que ambas as orientações tratam, portanto, de uma compreensibilidade ou de uma mediação: interpretar é procura do sentido interno por detrás do que foi expresso, enquanto o expressar anuncia algo interior (GRONDIN, 1999, p. 52) ${ }^{1}$.

Além dessa análise etimológica, e de certa forma a ela relacionada, é possível apresentar cinco conceituações modernas a fim de que se possa restringir conceitualmente o que se quer dizer quando se fala em hermenêutica ${ }^{2}$. As conceituações referidas são i) uma teoria da exegese bíblica; ii) uma metodologia filológica geral; iii) uma ciência de toda a compreensão linguística (Schleiermacher); iv) uma base metodológica das ciências do espírito (Dilthey); e v) uma fenomenologia da existência e da compreensão existencial (Heidegger-Gadamer).

O significado mais antigo da palavra hermenêutica diz respeito aos princípios da interpretação bíblica. Há uma justificação: a palavra encontrou seu uso atual precisamente quando surgiu a necessidade de regras para a exegese adequada das Escrituras Sagradas. Nesta conceituação, nota-se uma tendência a confiar num sistema de interpretação a partir do qual as passagens individuais possam ser 
interpretadas: a hermenêutica é o sistema que o intérprete tem para encontrar o significado oculto do texto (PALMER, 1999, p. 44-46). Desenvolvida para aclarar o significado dos caminhos divinos, o protestantismo criou a hermenêutica. Essas estratégias hermenêuticas surgiam apenas quando o texto bíblico parecia resistente às explicações mais fáceis: o entendimento era a regra (LAWN, 2007, p. 66-67).

Mais adiante, o desenvolvimento do racionalismo e concomitantemente o advento da filologia clássica do século XVIII surtiu um efeito profundo na hermenêutica bíblica. Nesse período, os intérpretes passaram a se sentir obrigados a tentar ultrapassar juízos prévios a fim de tornar a Bíblia relevante para o homem racional do Iluminismo. Aqui a interpretação bíblica fez desenvolver técnicas de análise gramatical de grande requinte, e os intérpretes comprometeram-se mais do que nunca num conhecimento total do contexto das narrações bíblicas. Os métodos da hermenêutica bíblica tornaram-se essencialmente sinônimos de uma teoria secular da interpretação - uma filologia clássica - e se transformou gradualmente numa hermenêutica considerada como conjunto de regras gerais da exegese filosófica, sendo a Bíblia um objeto entre outros de aplicação dessas regras (PALMER, 1999, p. 44-49).

Posteriormente, Schleiermacher repensa a hermenêutica como ciência ou arte da compreensão, o que acaba por implicar uma crítica radical do ponto de vista da filologia, pois procura ultrapassar o conceito de hermenêutica como conjunto de regras. 0 resultado não é simplesmente uma hermenêutica filológica, mas uma hermenêutica geral cujos princípios podem servir de base a todos os tipos de interpretação (PALMER, 1999, p. 50). Não obstante, por arte da compreensão Schleiermacher não quer dizer que a hermenêutica se manifeste como mero processo criativo e subjetivo. À época, "arte" incluía a ideia de saber como fazer alguma coisa. Assim, a arte surge como algo para o qual reconhecidamente se demandam regras. A hermenêutica como arte da compreensão tem como objetivo compreender corretamente aquilo que foi expresso por outro alguém, especialmente de forma escrita (SCHMIDT, 2014, p. 26). Além disso, apenas a partir de Schleiermacher que a hermenêutica transcende os limites que a atavam às particularidades para alcançar um novo sentido: a disciplina que se questiona sobre as condições 
genéricas da compreensão deveria estabelecer as regras que permitiriam a compreensão não só de textos científicos setorizados (hermenêutica bíblica, jurídica, literária, etc.), mas de todo o pensamento expressado em palavras (PEREIRA, 2006, p. 12).

Wilhelm Dilthey, por sua vez, vê na hermenêutica a disciplina central que serviria de base para todas as disciplinas centradas na compreensão da arte, comportamento e escrita do homem (ou ciências do espírito). Dilthey encontrou na hermenêutica - disciplina centrada na interpretação, e especificamente na interpretação de um objeto sempre histórico, um texto - a base mais humana e histórica para o seu próprio esforço de formulação de uma metodologia verdadeiramente humanística das ciências do espírito (PALMER, 1999, p. 50-51). Dilthey acredita que a metodologia das ciências naturais não seja adequada à compreensão das ciências humanas, pois os objetos das ciências humanas são constituídos por atos de seres humanos conscientes. Por outro lado, as teorias idealistas não fornecem a base empírica pertinente para as suas conclusões. Daí a relevância de as ciências humanas terem uma metodologia própria: a compreensão, em oposição à explicação, surge como metodologia própria das ciências naturais (SCHIMDT, 2014, p. 51). De fato, a grande contribuição de Dilthey foi situar a compreensão, ainda que limitada ao âmbito das humanidades, dentro da história e não fora dela, divergindo de quem acreditava possível a utilização dos métodos das ciências naturais - portanto, a-históricos - para interpretação dos fenômenos da vida, que inexoravelmente estão imersos no mundo histórico (PEREIRA, 2006, p. 16).

A última conceituação surge a partir de Heidegger - que, ao tratar do problema ontológico, voltou-se para o método fenomenológico do seu mentor Edmund Husserl, e empreendeu um estudo fenomenológico da presença do ser-no-mundo. A hermenêutica não se referiria à ciência ou às regras da interpretação textual e nem mesmo a uma metodologia para a interpretação das ciências do espírito; antes, a hermenêutica sugeriria uma explicação fenomenológica da própria existência humana. A análise de Heidegger indica que a compreensão e a interpretação são modos fundantes da existência humana. Assim, a hermenêutica heideggeriana do Dasein, transforma-se também em hermenêutica, especialmente na medida em que 
apresenta uma ontologia da compreensão; a sua investigação é de caráter hermenêutico, quer nos conteúdos quer no método. Gadamer desenvolve as implicações do contributo de Heidegger e põe a hermenêutica numa fase linguística com a afirmação de que "um ser que pode ser compreendido é linguagem". A hermenêutica seria um encontro com o ser através da linguagem. A hermenêutica se colocaria no centro dos problemas filosóficos de hoje; não se poderia fugir às questões epistemológicas e ontológicas, pois a própria compreensão torna-se epistemológica e ontológica (PALMER, 1999, p. 51-52). Em Heidegger, a hermenêutica passa a significar uma fenomenologia da existência. Deixa-se de falar na compreensão num sentido de propriedade para se concebê-la como um modo de existência, um elemento constitutivo do próprio Dasein. Finalmente, em Gadamer surge uma crítica radical ao pensamento científico-espiritual que perdurou por todo o século XIX, tornando-a uma hermenêutica filosófica, que passa a investigar o fenômeno da compreensão em si mesmo, isto é, passa a ter como finalidade explicitar o que ocorre nesta operação fundamental do compreender (PEREIRA, 2006, p. 17).

\section{UMA TRADIÇÃO ANTERIOR À HERMENÊUTICA FILOSÓFICA: SCHLEIERMACHER, DILTHEY E HEIDEGGER}

Feitas as considerações supra sobre uma análise etimológica do vocábulo hermenêutica e das conceituações modernas mais relevantes, passa-se à leitura do pensamento dos autores que mais influenciaram Gadamer, a saber: Schleiermacher, Dilthey e Heidegger. Cada um desses autores tem fundamental importância na consolidação do que vem a ser o "todo" do pensamento gadameriano. A escolha desses autores não é arbitrária, mas observa o pensamento de autores que, cada um na sua medida, solidificaram pilares da derradeira proposta de Gadamer de uma hermenêutica filosófica.

De fato, a escolha de Friedrich Schleiermacher, Wilhelm Dilthey e Martin Heidegger antes da exposição da hermenêutica filosófica de HansGeorg Gadamer não é aleatória: Richard Palmer, em sua Hermenêutica, crava como título da segunda parte "Quatro grandes teóricos", em 
referência aos quatro autores ora citados, que encabeçam os subcapítulos da referida parte. Dessa forma, seguindo os passos de Palmer - que além de redigir um dos mais conhecidos livros sobre hermenêutica da atualidade foi aluno do próprio Gadamer - deduz-se que a contribuição dos três primeiros autores citados tem especial relevância para a compreensão da proposta gadameriana. Acredita-se que a partir da leitura do pensamento desses autores será viável sintetizar um percurso histórico rumo à hermenêutica filosófica.

\section{SCHLEIERMACHER: HERMENÊUTICA COMO ARTE DA COMPREENSÃO}

Schleiermacher é o primeiro que interessa a este trabalho, principalmente por sua decisiva contribuição na construção de uma hermenêutica universal entendida como arte da compreensão: a preocupação originária de Schleiermacher era enfrentar a questão sobre como toda expressão linguística (falada ou escrita) é compreendida. É em Schleiermacher que hermenêutica e compreensão se identificam. Ou, como diz com maior precisão o próprio Gadamer, a relevância do autor em comento é que "Schleiermacher foi o primeiro a, movido profundamente pelo espírito do romantismo, abrir o espaço mais amplo possível para o contexto do problema da compreensão" (2012, p. 202). Com efeito, Schleiermacher foi o primeiro a conceber uma hermenêutica de pretensão universal suficientemente sólida:

Até aí [período anterior a Schleiermacher] a hermenêutica clássica e a bíblica tinham se desenvolvido paralelamente. Não deveriam ambas ser concebidas como aplicação de uma hermenêutica geral? Meier, o seguidor de Wolf, deu este passo em seu ensaio sobre uma arte universal da interpretação, de 1757. Ele concebia sua ciência verdadeiramente de forma tão geral quanto possível: ele deve esboçar as regras a serem observadas em qualquer interpretação de sinais. Mas o livro mostra mais uma vez que não se pode inventar novas ciências partindo de perspectivas arquitetônicas e simétricas. Assim surgem apenas janelas falsas, pelas quais ninguém pode ver. Uma hermenêutica efetivamente poderosa só poderia surgir numa mente em que se unisse $o$ virtuosismo na interpretação filológica com a real capacidade filosófica. Uma tal mente era Schleiermacher (DILTHEY, 1999, p. 25). 
A partir do Renascimento são fixados três tipos básicos de técnica de interpretação: teológica, filosófico-filológica e jurídica. No entanto, o problema predominante à época sobre as técnicas de interpretação aparece reorientado depois de Kant, pois surge a necessidade de se fornecer as condições gerais da compreensão e as razões dos processos de interpretação. A hermenêutica de Schleiermacher é posta por Dilthey como fundamento das ciências humanas contra a pretensão universal da metodologia positivista das ciências naturais. Estabeleceu-se, assim, uma nova inteligibilidade própria às ciências humanas, compreensiva, diferente da oriunda das ciências naturais, que é explicativa. Enquanto as ciências humanas visam à apreensão de significados intencionais, as ciências naturais pretendem explicar relações de causa e efeito. Assim, a hermenêutica contemporânea terá em Schleiermacher o seu precursor, pois a problemática da compreensão aparecerá no núcleo de obras como Ser e Tempo, de Heidegger, e Verdade e Método, de Gadamer (BRAIDA, 1999, p. 7-8)

Em Schleiermacher, o que se põe como objeto não são mais as especificidades da exegese bíblica ou da interpretação e compreensão filológicas; antes, o nível de discussão transcende as particularidades dos textos e das regras nas quais se dispersava a arte de compreender (RUEDELL, 2012, p. 77). Enquanto a hermenêutica era vista até Schleiermacher como uma construção de regras cujas partes, as regras particulares, eram mantidas num conjunto comum por causa do alvo de uma interpretação com validade universal, depois a problemática se volta a um ponto prévio, à própria análise do compreender (DILTHEY, 1999, p. 26). Para alcançar este desiderato, Friedrich Schleiermacher pressupõe a universalização do mal-entendido: a melhor compreensão, como finalidade inalcançável da compreensão, consiste no fato de que jamais se entendeu perfeitamente, de tal forma que uma penetração mais profunda no assunto interpretado sempre compensa. Dessa forma, Schleiermacher pressupõe que por detrás de cada palavra, falada ou escrita, há sempre algo diverso, algo pensado, que é propriamente o alvo da interpretação (GRONDIN, 1999, p. 129).

Nesse sentido, Schleiermacher pensou a unificação do realismo e do idealismo, o que significava para ele pensar conjuntamente o 
universal e o particular, o ideal e o histórico. Schleiermacher pressupõe uma incontornável relatividade do pensamento que inexoravelmente desagua na relatividade do próprio saber. Para tanto, é discutida uma inseparabilidade de pensamento e linguagem e a inexistência ou a impossibilidade de uma linguagem universal. Um saber absoluto pressupõe uma linguagem universal, o que é impossível. Ademais, Schleiermacher coloca na base da formação dos seus conceitos uma circularidade semelhante àquela atribuída às palavras e às frases: o juízo pressupõe conceitos, e os conceitos, por sua vez, pressupõem os juízos. Tal consideração leva à postulação e uma dependência mútua entre dialética e hermenêutica: o universal nunca se oferece em si, mas sempre aparece sob uma forma particular; o particular, em contrapartida, ao mesmo tempo que não se integra totalmente ao universal, contém em si algo que ultrapassa a sua particularidade e manifesta a presença do universal. A hermenêutica mostra os limites da dialética e a dialética possibilita a hermenêutica (BRAIDA, 1999, p. 11-14). Essa especial interação entre dialética e hermenêutica desagua no conceito de círculo hermenêutico, que é, sem dúvidas, essencial para a assimilação da hermenêutica filosófica gadameriana.

Seguindo esse conceito, compreender manifesta-se como uma operação essencialmente referencial: compreende-se algo quando se compara a algo conhecido. Dessa forma, numa interação dialética entre o todo e a parte, um dá sentido ao outro e deste modo se apresenta a forma circular: o círculo hermenêutico propõe uma área de compreensão partilhada. Assim, partindo-se do pressuposto de que a comunicação é uma relação dialógica, presume-se desde o início uma comunidade de sentido (PALMER, 2011, p. 94) ${ }^{3}$. Em última instância, a proposta em Schleiermacher, é de que o "alvo final do procedimento hermenêutico é compreender o autor melhor do que ele próprio se compreendeu" (DILTHEY, 1999, p. 31), pois o exercício hermenêutico de Schleiermacher propõe uma reconstrução das condições de origem de forma que seja possível ao intérprete vislumbrar conscientemente no autor algo que para ele próprio permaneceu inconsciente.

Nesse sentido, o significado de Schleiermacher para a história da hermenêutica (e também para Gadamer) é que a sua contribuição marcou 
uma viragem na história desta disciplina, pois após Schleiermacher a hermenêutica deixa de ser vista como um tema disciplinar específico e passa a ser entendida enquanto a arte de compreender uma expressão linguística. Então, a orientação que leva como ponto de partida o problema do conhecimento torna-se um solo fértil para a teoria da interpretação, que só depois de muitos anos pôde avançar com a hipótese de que as constantes na compreensão poderiam ser melhor observadas em termos históricos. Ou: apreendeu-se a importância da pré-compreensão na compreensão ${ }^{4}$. Assim, Schleiermacher ultrapassou decisivamente a hermenêutica como um conjunto de métodos acumulados por tentativas e erros e sustentou uma arte geral da compreensão prévia a qualquer arte especial de interpretação (PALMER, 2011, p. 100-101).

\section{DILTHEY: HERMENÊUTICA COMO FUNDAMENTO DAS CIÊNCIAS DO ESPÍRITO ${ }^{5}$}

Dilthey surgiu como o metodólogo da Escola Histórica: com a pretensão de proteger as ciências humanas em seu próprio direito científico contra o avanço da metodologia das ciências naturais. Esse autor pretendeu justificar bases gnosiológicas universalmente válidas para o seu campo (GRONDIN, 1999, p. 147). Assim, perto do final do século XIX, começou a vislumbrar na hermenêutica o fundamento que precisava (PALMER, 2011, p. 105). No entanto, antes de tudo, é necessário dizer que foi em Schleiermacher que Dilthey viu as bases para a construção de sua teoria: a ideia da hermenêutica como fundamento das ciências humanas surge do interesse de Dilthey pela proposta de Schleiermacher. E ele mesmo diz isso:

A hermenêutica deve fundamentar teoreticamente a validade universal da intepretação - sobre a qual se baseia toda a certeza da história - em contraposição à contínua invasão da arbitrariedade romântica e da subjetividade cética no âmbito da história. Concebida na conjunção entre teoria do conhecimento, lógica e metodologia das ciências humanas, esta teoria da interpretação [de Schleiermacher] se torna um importante elo de ligação entre a filosofia e as ciências históricas, ela se torna um elemento principal para a fundamentação das ciências humanas (1999, p. 32). 
Mas para construir essa metodologia foi necessário complementar a crítica da razão pura de Kant com uma crítica da razão histórica: a crítica da razão pura fez época não só por destruir a metafísica como pura ciência racional do mundo, mas porque, ao mesmo tempo, demostrou um domínio no qual o emprego de conceitos apriorísticos se justificava, isto é, porque respondeu à pergunta sobre como seria possível uma ciência natural pura. Assim, Dilthey viu a necessidade de desenvolver o mesmo engenho em relação às ciências humanas, pois aos olhos da escola histórica a filosofia especulativa da história representava um dogmatismo crasso exatamente como fora a metafísica tradicional, e por esta razão se deveria exigir uma fundamentação filosófica do conhecimento histórico, assim como Kant fez para as ciências naturais (GADAMER, 2014, p. 297-298). Não obstante, para compreender a proposta apresentada por Dilthey em complemento à empreitada de Kant, é preciso primeiro ter em mente os seus problemas e os seus objetivos e ainda se debruçar ao menos sobre dois pontos: a compreensão do que significava história e vida no pensamento de Dilthey.

Sobre a história, podem ser apresentados dois significados: em primeiro lugar, que o ser humano não se compreende pela introspecção, mas, sim, por meio de objetivações da vida: "o que o homem é, só a história pode dizer"; em segundo lugar, significa que a natureza humana não é e nem se apresenta como uma essência fixa. Daí que, na teoria hermenêutica diltheyana, o homem é visto em dependência relativamente a uma intepretação constante do passado e, assim, quase se poderia dizer que o homem é o "animal hermenêutico" que se compreende a si próprio em termos de interpretação de uma herança e de um mundo partilhados que o passado lhe transmite, isto é, uma herança constantemente presente e ativante em todas as suas ações e decisões (PALMER, 2011, p. 121-123).

Além disso, e em correlação à historicidade, é preciso compreender a temporalidade: num sentido existencial, o tempo surge como uma unidade mínima de compreensão das vivências em seus três estados (passado, presente e futuro), de forma a constituir uma presença na qual a vida se entende como uma unidade de sentido. 0 caráter hermenêutico da presença se resume na unidade de sentido e na confluência entre o passado vivido, o presente que o combina e o futuro como possibilidade 
de realização. Ao contemplar o futuro, este indica a possibilidade de uma ação aberta em respeito ao nosso presente, a liberdade. Esta possibilidade que implica o futuro se encerra dentro da capacidade de ação que tem o indivíduo no presente. No entanto, o presente não é nada além de uma efetuação do passado (CATOGGIO, 2012, p. 294-295).

Quanto ao conceito de vida no pensamento de Dilthey, a dinâmica da vida interior aparece como um conjunto complexo de cognição, sentimento e vontade, fatores que não se sujeitam às normas de causalidade e à rigidez de um pensamento mecanicista e quantitativo. Assim, o objetivo das ciências humanas não pode ser a compreensão da vida em termos categoriais exteriores à vida, mas deve ser a partir de categorias intrínsecas, isto é, a vida só pode ser compreendida a partir da própria experiência de vida (PALMER, 2011, p. 109). Ademais, o conceito de vivência aparece como palavra-chave para a compreensão da hermenêutica diltheyana, pois a ponte da vivência constrói o conceito de compreensão para as ciências humanas: não é pelo objeto que as ciências humanas se diferenciam das ciências naturais, e sim pela relação diversa que possui com o objeto (GRONDIN, 1999, p. 151) . $^{6}$

Nesse sentido, é permitido dizer que a partir desses conceitos (de vida e historicidade) se concebe a consciência histórica: a consciência histórica em Dilthey obriga a compreensão do mundo e da própria vida a partir da temporalidade, de forma que tudo se dá em termos históricos de modo que não é mais possível falar em pressupostos e conceitos atemporais: lançam-se novos olhos sobre o ser, pois o próprio ser passa a ser histórico, e isto é decisivo para Heidegger e Gadamer ${ }^{78}$.

Em verdade, Dilthey contribuiu para alargar o horizonte da hermenêutica colocando-a no contexto da interpretação dos estudos humanísticos e isto satisfez dois objetivos básicos: em primeiro lugar, focou o problema da interpretação num objeto com estatuto fixo, duro e imutável, de forma que os estudos humanísticos pudessem ofertar um conhecimento objetivamente válido, pois o objeto em si seria relativamente imutável; em segundo lugar, Dilthey apelava para modos históricos de compreensão, mais do que para modos científicos, a fim de que só se pudesse compreender em referência à própria vida em toda a sua historicidade e temporalidade. Assim, a hermenêutica se pôs no 
horizonte da historicidade e se colocou os fundamentos do pensamento de Heidegger na temporalidade da autocompreensão (PALMER, 2011, p. 127-128). Além disso, com Jean Grondin é possível dizer que há um significado especial na hermenêutica diltheyana, pois a filosofia hermenêutica do século XX, estimulada por Dilthey tanto no âmbito da sua própria Escola como nas mais evoluídas teses de Heidegger e Gadamer, vai reconhecer a improcedência do método e contra este vai opor o universalismo da historicidade (1999, p. 155).

\section{HEIDEGGER: HERMENÊUTICA DA FATICIDADE}

A hermenêutica de Martin Heidegger dá um passo decisivo quando faz do fenômeno da compreensão algo maior do que uma mera forma de conhecimento ou sistema de regras. Heidegger avança quando vê na hermenêutica uma determinação ontológica do próprio homem e algo característico da própria filosofia quando a reconhece como forma de abertura do ser ao homem (MAZA, 2005, p.122). Em Heidegger a hermenêutica vai constituir um modo de ser do próprio Dasein, que sempre será um ente eminentemente hermenêutico, qualificado pela capacidade de compreender a si mesmo e ao mundo.

A contribuição de Dilthey foi incontestável para a hermenêutica de Heidegger (assim como a contribuição de outros filósofos da vida, como Nietzsche). Contudo, não só a influencia diltheyana bastaria para a proposta incipiente de Heidegger de levar a cabo uma hermenêutica como modo de ser próprio do Dasein, as ideias de outros autores também foram essenciais, como Edmund Husserl. Todavia, Heidegger não se limita nem a Husserl nem a Dilthey; mas, antes, avança em relação a ambos na construção de uma nova ontologia que, necessariamente, pressupõe uma nova hermenêutica (que será esmiuçada adiante).

Em primeiro lugar, Husserl propunha a ideia da Fenomenologia Transcendental, à qual Heidegger vai opor uma Fenomenologia Hermenêutica. 'A palavra 'fenomenologia' exprime uma máxima que se pode formular na expressão: 'para as coisas elas mesmas!'” (HEIDEGGER, 2014, p. 66 $)^{9}$. A partir desse conceito geral de fenomenologia, é possível 
começar a compreender essa distinção. Enquanto Husserl sugere um recuo aos atos conscientes do Eu Transcendental em seu intento fenomenológico de recuperar a dimensão objetiva do mundo, Heidegger se pergunta se de fato seria necessário esse recuo. Veja:

Heidegger se pergunta se essa ideia da constituição transcendental de mundo exige esse recuo ao Eu transcendental, à consciência e à representação. Por que não descobrir a constituição transcendental de mundo em um ente do mesmo nível do próprio conceito de mundo? Isso significaria, então, que o conceito de mundo não exigiria a constituição de uma esfera transcendental de representação, mas pdoeria ser descoberto na própria descrição de um ente no qual se daria esse conceito de mundo [...] Segundo Heidegger, é preciso mostrar que o ser do Dasein é totalmente diferente daquele dos outros entes. Se a constituição do Dasein é totalmente diferente da constituição dos outros entes, então é possível encontrar nele mesmo o acontecer transcendental. Desnecessária a operação de "pôr o mundo entre parênteses", recuar ao Eu transcendental, ao mundo da representação, para depois então recuperar o mundo fático. A constituição transcendental é uma possibilidade central da existência do próprio Dasein (STEIN, 2011, p. 64-65).

Em Heidegger, o Dasein é um ente que se distingue dos demais por um primado que lhe permite compreender a si mesmo enquanto ser, isto é, sendo, manifestando então e também um primado ontológico. Além disso, o Dasein é um ente que goza de um primado ôntico-ontológico que se apresenta na possibilidade de todas as ontologias; ou seja, manifesta-se num primado em que a partir do Dasein, e só a partir do Dasein, todas as coisas podem manifestar o seu ser, isto é, sendo [no horizonte da temporalidade]. Heidegger diz:

[A] presença [Dasein] possui um primado múltiplo frente a todos os outros entes. 0 primado ôntico: a presença [Dasein] é um ente determinado em seu ser pela existência. 0 segundo é um primado ontológico: com base em sua determinação de existência, a presença [Dasein] é em si mesma "ontológica". Pertence à presença [Dasein], de maneira igualmente originária, e enquanto constitutiva da compreensão da existência, uma compreensão do ser de todos os entes que não possuem o modo de ser da presença [Dasein]. A presença [Dasein] tem, por conseguinte, um terceiro primado, que é a condição ôntico-ontológica da possibilidade de todas as ontologias. Desse modo, a presença se mostra como o ente que, ontologicamente, deve ser o primeiro interrogado, antes de qualquer outro (2014, p. 13). 
A partir da qualidade constitutiva do Dasein frente aos demais entes, torna-se necessária uma hermenêutica do mundo a partir do próprio Dasein, pois a denúncia dessa desnecessidade de um recuo a determinado Eu transcendental denuncia a fragilidade das bases da própria filosofia da consciência ${ }^{10}$ e consequentemente da Fenomenologia transcendental. Assim, a fenomenologia de Heidegger avança em relação à fenomenologia husserliana por se calcar no Dasein - que, frise-se, não se confunde, por exemplo, com o Eu penso cartesiano ou o Eu transcendental husserliano - e que se difere por se tratar de um ente capaz de compreender a si mesmo e também como um ente que se manifesta enquanto ser-no-mundo, um ente que se compreende ontologicamente imerso no mundo. Assim, não se coloca o Dasein acima, antes ou além do mundo: fala-se num ente sempre imerso no mundo e que apreende esse mundo dentro de suas limitações e à luz da temporalidade ${ }^{11}$. Veja:

Husserl não quer mais cair no dualismo kantiano do fenômeno e da coisa em si, ele tenta levar seu projeto a um sistema, mas que não consegue concluir na impossibilidade de recuperar o mundo vivido. No momento em que se quer pensar a totalidade não reduzida do mundo, quer se pensar o mundo na medida em que ele é; nós nos confrontamos com o problema da compreensão do ser. Essa compreensão do ser, por sua vez, dá-se no Dasein, e, por isso, ela não é uma compreensão que pode ser atingida por meio da representação e da consciência. Trata-se de uma compreensão que pode ser descrita ao modo de se dar no mundo. A ideia ser-no-mundo, a ideia de mundo, está ligada a esta ideia da compreensão do ser, que nunca pode se esgotar como totalidade absoluta, mas que sempre é uma compreensão que se dá nas condições do Dasein. Como as condições do próprio Dasein fazem com que todos os entes com os quais ele entra em contato percam a positividade, a analítica existencial procura dar conta desse espaço para onde Dasein e mundo elevam os entes simplesmente existentes, os entes à mão ou entes disponíveis a uma dimensão ontológica. Isso pode ser feito a partir de uma fenomenologia que parte da ideia da compreensão do ser e da compreensão do Dasein enquanto ele é. Assim, não fica mais algo fora, que sustenta o Dasein sem que ele se pense enquanto é (STEIN, 2011, p. 67-68).

Mas não é só a partir de Husserl, ou do distanciamento de Husserl, que Heidegger constrói sua proposta hermenêutica. Antes, o distanciamento de Husserl exige a apreensão da temporalidade e da historicidade como inerentes à compreensão do ser. Mas a apreensão da 
temporalidade e da historicidade enquanto instâncias condicionadoras da compreensão do ser-no-mundo parecem remeter necessariamente a um retomar de Dilthey ${ }^{12}$. Isto porque é na temporalidade que Heidegger vê as pistas indicativas sobre a natureza do ser: o ser, tal como se revelaria na experiência vivida, escaparia às categorias conceituais e atemporais - e Heidegger pretendia demonstrar isto (PALMER, 2011, p. 129-130).

Em suma, Heidegger "procurava desenvolver uma "hermenêutica da facticidade", onde a própria existência concreta já sempre dada seria a base para toda investigação fenomenológica" (MISSAGIA, 2012, p. 2). A abertura de um fenômeno só é possível a partir de uma pré-compreensão, que vai se revelar inadequada se conduz a distorções e encobrimentos e adequada se se mostra fecunda para expor o fenômeno que se pretende compreender. Em vez de um critério absoluto de evidência, há que se considerar a radicalidade da finitude e a historicidade de todo esforço cognoscitivo (MAZA, 2005, p. 125) ${ }^{13}$.

A hermenêutica da faticidade se questiona sobre a situação hermenêutica a partir da qual é possível compreender o ser da vida fática. Para Heidegger, não se poderia adotar nenhuma atitude sem antes implicar num modo de se situar na relação de desvelamento. Em verdade, não existe a pura autotransparência na pesquisa teórica, um puro reflexo neutro do que se é. 0 olhar fenomenológico tem uma estrutura intencional determinada pela própria vida fática, em que se assenta toda a forma de se olhar (MAZA, 2005, p. 125) Embora possa parecer que essa hermenêutica conduza ao relativismo absoluto, conceitos inerentes à compreensão da hermenêutica da faticidade cerceiam perspectivas quando se põem na soma variáveis intersubjetivas que as condicionam [as perspectivas]. Veja:

Temos a faticidade, a existência e a decaída, e estes três conceitos resultam das características do cuidado: já-ser-adiante-de-si-mesmo (existência), já-sempre-no-mundo (faticidade), junto-das-coisas (decaída). Sobre elas aparece a tríplice dimensão da temporalidade: a existência, o futuro; a faticidade, o passado, e a decaída, o presente. Então, temos uma espécie de cerceamento das condições transcendentais nas quais desde sempre o Dasein é ser-no-mundo [...] A fenomenologia hermenêutica não cai nem no impasse de quem quer recuperar a totalidade do mundo vivido, porque aceita a faticidade, nem cai também num impasse de pretender um sistema absoluto, como Husserl o ambicionava (STEIN, 2011, p. 69). 
Ainda sobre essas condicionantes, é imprescindível a compreensão das implicações da noção de faticidade:

A noção de facticidade parece apontar um problema na medida em que trata daquilo diante do qual "não se pode voltar atrás", isto é, daquilo que necessariamente está já estabelecido e do qual devemos sempre partir, que é o fato mesmo da vida presente. Essa vida, ainda que sempre a constatemos como algo atual no instante mesmo em que a percebemos, não está isolada de um contexto e de um fluxo temporal: a facticidade da vida é envolta sempre por um passado carregado de significação (incluindo os prejuízos a ela inerentes) e aponta para as projeções que podemos fazer em relação ao futuro. Uma vez que vivemos num contínuo fluxo temporal é natural que possamos fazer certas previsões, com base nos conhecimentos passados, sobre aquilo que pode acontecer; estamos necessariamente abertos para nossas possibilidades, cientes de sua existência. Do mesmo modo, toda atitude presente não é encarada em si mesma, mas envolve esse contexto determinado pelo conhecimento já adquirido. Esse aspecto do "horizonte temporal" do conceito de facticidade certamente tem seus reflexos na hermenêutica gadameriana, o que é também evidenciado pelo grande interesse de Gadamer pelo tema (MISSAGIA, 2012, p. 2).

A hermenêutica da faticidade e todos os conceitos que lhe são correlatos derrubam a subjetividade pura ao reconhecerem a interpretação do Dasein já sempre contaminada pelo mundo no qual ele é lançado, isto é, a interpretação do Dasein está sempre contaminada pela faticidade diante de um mundo que o antecipa e que, consequentemente, o impregna de pré-compreensões. Dessa forma, e esse é o diferencial de Heidegger, o fenômeno hermenêutico há de se operar justamente no esclarecimento dessas pré-compreensões historicamente dadas, reconhecendo a historicidade e a temporalidade supramencionadas como fio condutor da interpretação, mas sem jamais desconsiderar o primado característico do Dasein de compreender o seu próprio ser e também todas as demais ontologias.

Para Heidegger, não é como se existissem coisas nuas a serem subjetivadas: o fenômeno interpretativo, de início, se dá precisamente com a relação do Dasein com o mundo, no modo de pré-estrutura da compreensão (ou pré-compreensões). Esses esboços, inicialmente, não são escolhidos; antes, o Dasein é jogado neles. 0 específico ser lançado e a 
historicidade do Dasein são as características permanentes da faticidade. Entretanto, o Dasein não está cegamente à mercê dessas pré-estruturas de explanação induzida. A hermenêutica de Heidegger é exatamente o oposto disso: é um explícito esclarecimento da pré-estrutura historicamente dada, chamado de interpretação (GRONDIN, 1999, p. 163).

Caminhando para as conclusões deste ponto, é necessário dizer que uma consequência manifesta da hermenêutica heideggeriana é o reconhecimento da finitude, e que isso, antes de uma limitação da compreensão, parece sugerir a ampliação das possibilidades de uma compreensão autêntica, o que, ao fim e ao cabo, é decisivo para hermenêutica filosófica de Gadamer. Assim, considerando a crítica de Nietzsche, Marx e Freud e a proposta de uma hermenêutica da faticidade levada a cabo por Heidegger, bem como a consequente crítica à autoconsciência e ao idealismo (isto é, à filosofia da consciência como um todo), Gadamer diz:

Dessa crítica ao conceito de consciência que Heidegger radicalizou mais tarde, aquilo que recebe um peso particular é o fato de Heidegger já ter introduzido antes de Ser e Tempo a expressão "hermenêutica da facticidade", a fim de contrapor o seu próprio modo de colocação do problema ao idealismo da consciência. Facticidade é mesmo manifestamente o inaclarável que resiste a toda a tentativa de alcançar a transparência da compreensão. A partir daí fica claro que permanece em toda compreensão de sentido algo impassível de ser esclarecido e que se precisa retrojetar a questão àquilo que motiva toda a compreensão. Com isso, altera-se todo o conceito de interpretação e ele se aproxima da radicalidade que encontramos acima na célebre sentença de Nietszche [“É preciso duvidar de maneira mais fundamental"]. Meus próprios trabalhos prosseguiram na direção daquilo que a interpretação é propriamente, quando se chega ao ponto de contestar de maneira fundamental o ideal da autotransparência da subjetividade. Não é apenas isso que se tem efetivamente em vista ao afirmar que sempre se encontrará de fato toda compreensão de sentido limitada, mas também que uma compreensão de sentido ilimitada encurtaria o sentido da compreensão. Sim, no fundo suprimiria, assim como uma perspectiva que a tudo abarcasse suprimiria o sentido da perspectiva (2007, p. 18-19).

Finalmente, é importante destacar que todas as questões relativas à analítica existencial è̀ hermenêutica da faticidade não fariam sentido se não houvesse uma linguagem, um campo de transcendência intersubjetivo 
e partilhado que permitisse a compreensão do fenômeno de desvelamento do ser. Desde o giro linguístico-pragmático, a linguagem passa a ser a casa do ser: sem a linguagem todos os seres se fechariam. Sem a linguagem, sequer seria dado ao ser humano compreender-se enquanto tal. Da mesma forma, constituindo implicação recíproca, é necessário que o ser humano compreenda que enquanto vive está sujeito à temporalidade, à historicidade, à finitude, etc., e que não seria possível a ruptura com as pretensões subjetivistas sem a consciência clara da provisoriedade de toda a existência ${ }^{14}$.

Além disso, mesmo se Heidegger não tivesse escrito mais nada depois de Ser e Tempo, a sua contribuição para a hermenêutica já seria decisiva: Heidegger supera Dilthey quando apresenta toda compreensão como temporal, intencional e histórica, e não apenas aquelas relacionadas às ciências do espírito. Além disso, supera outros pensadores por apresentar o processo de compreensão não com um mero processo mental, mas como um processo ontológico. Antes de Heidegger se tinha como certa a definição prévia daquilo que era real e só depois se perguntava como é que os processos mentais albergavam essa realidade. Com ele, no entanto, se apresentou a compreensão como um passo prévio indicativo do ato de fundamentação e revelação da realidade (PALMER, 2011, p. 145). Ademais, Heidegger vai colocar o ser humano numa espécie de relação hermenêutica em que ele é próprio mensageiro. É o ser humano que constrói a ponte entre o ser e o não-ser. 0 ser humano, ao falar, interpreta o ser. Mas para tanto Heidegger vai colocar a linguagem não como mera expressão do ser humano, mas verdadeiramente como aparição do ser: o pensamento não exprime o ser humano, mas deixa que o ser aconteça como evento linguístico (PALMER, 2011, p. 153-159).

Heidegger promove um retorno aos gregos, só que levando a sério o que a modernidade trouxe de bom consigo. 0 projeto heideggeriano também surge no sentido de estabelecer um diálogo entre o ser e o tempo, nos moldes propostos principalmente por Dilthey, quem de fato primeiro vai colocar a questão da temporalidade e da historicidade. Veja:

O hermeneutic turn protagonizado por Heidegger significou, de certo modo, uma volta à filosofia grega para sanar as limitações da razão moderna, 
pois, na retomada de Aristóteles e dos pré-socráticos, tentou fundamentar a ontologia e a metafísica a partir da relação entre ser e tempo. A virada operada por Heidegger e Gadamer é, de certo modo, pois, uma volta à antiguidade, que procurou levar consigo os benefícios da modernidade (ROHDEN, 2002, p. 74).

Dito isso, acredita-se ter exposto como é essencial a compreensão da filosofia de Heidegger como condição de possibilidade para compreensão da hermenêutica levada a cabo por Gadamer. Assim, finalmente é possível iniciar os estudos da hermenêutica filosófica de Gadamer, que, ao fim e ao cabo, constitui o último objetivo deste artigo.

\section{NOÇÕES GERAIS DA HERMENÊUTICA FILOSÓFICA E COMENTÁRIOS SOBRE O MÉTODO NO DIREITO}

Não parece demais afirmar que toda a narrativa empreendida até agora foi com vistas à adequada compreensão do que será elaborado nesta seção. Com efeito, tudo foi dito para viabilizar a compreensão do chamado hermeneutic turn - operado por Heidegger e levado às últimas consequências por Gadamer na constituição de sua hermenêutica filosófica. Além disso, a compreensão da hermenêutica filosófica de Gadamer é condição de possibilidade para se pensar uma hermenêutica jurídica a partir de Gadamer, seja puramente a partir de Gadamer, como faz Hernández-Largo, ou, parcialmente influenciada por Gadamer, como fazem Friedrich Muller, Eros Roberto Grau e Lenio Luiz Streck, por exemplo.

A hermenêutica filosófica se apresenta como uma teoria geral do saber. Enquanto se opõe à metafísica e à ontologia clássica e moderna, a hermenêutica filosófica, ao pretender articular lógica e ontologia, historicidade e cientificidade, verdade e método, contempla um pensamento autenticamente "forte", pois não reconhece nenhum jogo de linguagem como absoluto. A hermenêutica filosófica é ampla porque não exclui a experiência e a contingência humana (ROHDEN, 2002, p. 111112). Em verdade, a hermenêutica filosófica de Gadamer se opõe a uma tradição de pensamento que lhe antecede especialmente por se pautar 
em pressupostos pragmáticos e intersubjetivos. Gadamer, seguindo os passos de Heidegger, se opõe à concepção de verdade absoluta e estática.

Um ponto de partida para a compreensão da hermenêutica filosófica é a analítica existencial do Dasein: a analítica existencial articulada por Heidegger demonstrou convincentemente que a compreensão é um modo de ser próprio do ser humano. Tem-se hermenêutica porque o ser humano é hermenêutico, finito e histórico; portanto, marcado por sua experiência de mundo. Assim, a pergunta fundamental é: que significa para a compreensão e autocompreensão do ser humano notar-se carregado por uma história, a qual tem acesso como linguagem dada pela tradição? 0 desafio de Gadamer é tentar explicitar a historicidade da compreensão como forma originária do ser-no-mundo (OLIVEIRA, 2006, p. 225-226).

Gadamer se pauta num conceito provisório de verdade (pragmático), que surge na temporalidade e se expressa em linguagem. De fato, Gadamer observa que a concepção de uma verdade absoluta só pode emergir da repressão ou do esquecimento da própria temporalidade (que já é posta como inafastável por Dilthey e Heidegger antes mesmo de Gadamer). Essa provisoriedade deságua num projeto de revisão da própria metafísica, promovendo um chamado hermeneutic turn, que rompe com o absoluto e propõe a preponderância do provisorium como novo fundamento da ontologia. Nesse sentido, veja:

O provisorium do princípio ontológico não é compreendido aqui no sentido de Descartes, mas como um provisorium constante, um enquanto, que pode ser justificado pela unidade essencial de fenômenos coerentes. A provisoriedade aqui é coerencial, válida e justificável por si em relação a nós e vice-versa, num determinado momento, não apenas enquanto busca de um fundamento inconcusso de conhecimento. 0 provisorium não é uma simples propedêutica, como a moral provisória, para a obtenção de um eternum. 0 entimema é um provisorium conceituai; contudo, nem por isso é superficial, insuficiente, ilógico ou irracional. 0 que é a história, se não o contingente fixado no tempo, uma conexão entre ordem e contingência? Infelizmente, como retórica, relativo, provisorium não soam e não são concebidos como filosóficos para uma determinada perspectiva filosófica. Talvez tenha chegado o tempo de podermos intitular - sem temer a academia - uma obra filosófica do seguinte modo: Traços fundamentais de uma hermenêutica filosófica, ou simplesmente hermenêutica filosófica (ROHDEN, 2002, p. 282-283). 
Ainda sobre o hermeneutic turn, não há duvidas de que Gadamer não se limita a Heidegger: Gadamer faz seu contributo pessoal para a história da filosofia e, principalmente, para a história da hermenêutica, quando radicaliza as possibilidades da hermenêutica para além dos limites postos por Heidegger. Nesse sentido, Stein ressalta que a virada hermenêutica é uma expressão que vem se tornando um anúncio de uma mudança na concepção tradicional de conhecimento. No entanto, não há de se encontrar em Heidegger o termo hermenêutica filosófica, que necessariamente está relacionado à fenomenologia hermenêutica. Quando Gadamer passa a falar em hermenêutica filosófica, realiza uma mudança significativa em relação a Heidegger, com implicações próprias. A hermenêutica filosófica de Gadamer recuou em relação às pretensões da filosofia hermenêutica de Heidegger; mas, ao mesmo tempo, ampliou a compreensão do próprio conceito de hermenêutica, dando-lhe envergadura extraída da própria filosofia e ainda tornando-a menos exigente no que se refere à sua diferenciação diante das hermenêuticas científicas. (2014, p. 208-209).

Além disso, embora Gadamer tenha acolhido o conceito de faticidade, o autor deixa de lado a questão transcendental que era a de máxima importância para Heidegger e aplica a faticidade no estudo do todo da cultura e da história. Assim, se o conceito de compreensão de Heidegger visava chegar ao problema do ser, num nível transcendental, em Gadamer a compreensão almeja um projeto de reconstituição da historicidade e do mundo vivido. A tarefa da filosofia, enquanto hermenêutica filosófica, consistirá na questão do sentido, relacionada à compreensão da historicidade do mundo vivido (STEIN, 2014, p. 212).

Efetivamente, a história tem um significado especial para Gadamer, e este ponto é essencial para justificar sua oposição ao historicismo. Enquanto para o historicismo era necessário uma espécie de objetividade das ciências humanas a partir da negação dos preconceitos, Gadamer vai apresentar tais preconceitos, moldados historicamente, como condição de possibilidade da própria compreensão. De fato, a pré-compreensão é o ponto de partida da própria compreensão.

Para Gadamer, foi uma ilusão tentar afastar os preconceitos (ou pré-compreensões) através de métodos, como que para possibilitar 
uma objetividade às ciências do espírito. Ironicamente, o próprio historicismo sustentou que cada doutrina deve ser entendida com base na sua época; pois bem, o próprio historicismo foi filho do seu tempo: do cientificismo. E aqui se coloca a questão mais crítica da hermenêutica: como se pode, enquanto se pode ter consciência delas, diferenciar as verdadeiras pré-compreensões das falsas, isto é, das pré-compreensões que conduzem a mal-entendidos? Se existisse um critério único, todos os problemas da hermenêutica estariam resolvidos. E a ambição por um critério que, de uma vez por todas assegurasse objetividade às ciências do espírito, foi a depoente metafísica do historicismo (GRONDIN, 1999, p. 186-188). É nesse caminho que Gadamer vai se colocar radicalmente contra a absolutização do método, que é filho da modernidade e inerente ao historicismo, e almeja um critério que permita uma objetividade inalcançável. Assim, embora por influência cartesiana a modernidade sustente o método como meio de acesso à verdade, Gadamer acredita que o método é sempre viciado por pressupor uma verdade implícita.

Para Gadamer, não se alcança a verdade metodicamente mas dialeticamente. Como antítese ao método, a abordagem dialética da verdade é um meio de ultrapassar a tendência do método em estruturar previamente o modo individual de ver. No método, o tema a investigar é orientado, controlado, manipulado; na dialética, o tema levanta as questões. A resposta só pode ser dada se pertencer ao tema e situandose nele; portanto, a situação interpretativa não se põe mais como a de um sujeito que interroga um objeto, devendo o interrogador construir métodos que lhe permitam o acesso ao objeto; antes, quem interroga se descobre como sendo o ser interrogado pelo tema (PALMER p. 169-170).

Exemplificativamente, sobre a relevância da compreensão contrametódica de Gadamer no âmbito do Direito, nota-se que a hermenêutica jurídica tradicional se mostra inegavelmente contaminada pelo pensamento idealista e subjetivista da modernidade. Em verdade, aposta nos métodos como único meio possível de acesso à compreensão: quando se fala em interpretação do direito fala-se em métodos filológicos, lógicos, sistemáticos, etc. como meio de acesso à compreensão. Porém, à luz da proposta de Gadamer esses métodos se mostra(ria)m inadequados e/ou 
insuficientes para compreender o próprio fenômeno da compreensão, principalmente depois do referido hermeneutic turn.

Veja o que diz Bonavides sobre interpretação no sentido clássico de Savigny:

Interpretação, no sentido clássico de Savigny, é a reconstrução do conteúdo da lei, sua elucidação, de modo a operar-se uma restituição de sentido ao texto viciado ou obscuro.

Trata-se evidentemente de operação lógica, de caráter técnico mediante a qual se investiga o significado exato de uma norma jurídica, nem sempre clara ou precisa.

Busca a interpretação portanto estabelecer o sentido objetivamente válido de uma regra de direito (2004, p. 437).

A fim de alcançar tal sentido objetivamente válido de uma regra de direito - sem desconsiderar as várias mudanças em seu pensamento no curso de sua fecunda vida acadêmica - Savigny há de se valer de métodos (ou cânones, ou elementos de interpretação), que hão de guiar os estudos da hermenêutica jurídica clássica com poucas variações. Nesse sentido, as colocações de Luís Roberto Barroso são pertinentes ${ }^{1516}$ :

Os elementos tradicionais da interpretação jurídica, na sistematização adotada no Brasil e nos países de Direito codificado, remontam à contribuição de Savigny. Expoente da ciência jurídica do século XIX, fundador da Escola Histórica do Direito, distinguiu ele, em terminologia moderna, os componentes gramatical, histórico, e sistemático na atribuição de sentido aos textos normativos. Posteriormente, uma quarta perspectiva foi acrescentada, consistente na interpretação teleológica. Com pequena variação entre os autores, este é o catálogo dos elementos clássicos da interpretação jurídica: gramatical, histórica, sistemática e teleológica. Nenhum desses elementos pode operar isoladamente, sendo a interpretação fruto da combinação e do controle recíproco entre eles. A interpretação, portanto, deve levar em conta o texto da norma (interpretação gramatical), sua conexão com outras normas (interpretação sistemática), sua finalidade (interpretação teleológica) e aspectos do seu processo de criação (interpretação histórica) (2013, p. 314).

Não obstante, tais métodos não prevalecem diante de uma reflexão hermenêutica de matriz gadameriana. Sobre isso Eros Roberto Grau é 
incisivo ao dizer que: “[a] reflexão hermenêutica repudia a metodologia tradicional da interpretação, submetendo a críticas a sistemática escolástica dos métodos, incapaz de responder à questão de se saber por quê determinado método deve ser, em determinado caso escolhido" (2014, p. 65). Ou, ainda, em síntese: "a insubsistência dos métodos de interpretação decorre da inexistência de uma metarregra ordenadora da aplicação, em cada caso, de cada um deles" (2014, p. 65). É dizer: não há como dizer, por exemplo, de qual método (cânone ou elemento) o intérprete deve se socorrer ou dar maior ênfase em determinado caso. Eis o ponto fulcral. Eis uma das razões que justificam a análise da proposta Gadameriana no âmbito jurídico, por exemplo.

Sem prejuízo do que foi exposto, questionar o método não significa a queda no puro arbítrio. Antes, a própria linguagem (numa perspectiva pragmática e intersubjetiva) se torna instância de controle ou aferição de verdade. Nesse sentido, diz Lenio Luiz Streck:

Se o método, para o paradigma da filosofia da consciência, é/foi o supremo momento da subjetividade, decretar a sua superação, como magistralmente fez Gadamer, não quer dizer que, a partir de então, seja possível "dizer qualquer coisa sobre qualquer coisa" ou "qualquer coisa que a consciência nos 'impõe"'. Ao contrário: se o método colocava a linguagem em um plano secundário (terceira coisa entre o sujeito e o objeto), manipulável pelo sujeito solipsista, a intersubjetividade que se instaura com o linguistic turn exige que, no interior da própria linguagem, seja feito o necessário controle hermenêutico (2013, p. 111).

Em verdade, em Gadamer se passa a ver o fenômeno de compreensão baseado no ser humano como ser histórico e também na linguagem e suas infinitas significações, o que, assim, exige a revisão de uma metódica que se esquece da provisoriedade, da temporalidade e da historicidade e, sobretudo, do respeito à linguagem. De fato, é inegável a realização da interpretação pela linguagem. Não obstante, a hermenêutica jurídica tradicional aparentemente insiste em tentar captar essências linguísticas, negando a historicidade inerente à interpretação do direito e a inafastável provisoriedade de sentido que contamina a interpretação de determinado dispositivo de lei, que 
sempre demandará atualização no momento da aplicação, como será disposto mais adiante. A esse respeito, diz Lenio Streck:

[A] dogmática jurídica ainda buscar capturar, na interpretação da lei, a essência das palavras. Ou seja, para grande parcela do pensamento jurídico pátrio, o problema da interpretação da lei estaria resolvido se fosse possível construir um grande dicionário onde estivesse contida toda a essência significativa transmitida pelas palavras [...] Nesse ponto, não é demais registrar que foi Heidegger quem mostrou que, em filosofia, é equivocado pensar nas palavras como fonte de "essências de significado" [...] Note-se: não é nas palavras que devemos buscar os significados do mundo (ou do direito, para ser mais específico), mas é para significar (o direito) que necessitamos de palavras [...] o Dasein, em seu modo prático de ser-no-mundo, desde sempre já se move - compreensivamente - em um todo de significados [...] Dito de outro modo: articulamos as palavras que temos disponíveis projetando sentido a partir deste todo de significados. Ou seja, o discurso - que é o modo de manifestação da linguagem - é articulado sempre imerso nesta dimensão de (pré)compreensibilidade da significância (2014, p. 497-498).

Feita essa breve digressão sobre o método e a relevância da linguagem para a interpretação do direito, é possível concluir no sentido de desde Gadamer a compreensão não se circunscreverá ao âmbito das ciências humanas; antes, a compreensão passará a transcender o marco metodológico e se constituir como a forma na qual verdadeiramente se expressa a existência (LOZADA, 2014, p. 99). De fato, a hermenêutica gadameriana será essencialmente universal: Gadamer põe as bases para se pensar a própria compreensão para além do método. Ademais, é lícito afirmar que toda a proposta da hermenêutica gadameriana se pauta no diálogo: a tentativa de explicitar um princípio ontológico por meio da linguagem, provisório e necessariamente contaminado pela experiência, radica em Gadamer no diálogo, o que evita a queda no solipsismo (inclui a intersubjetividade na interpretação). Na linguagem, que é uma experiência histórica e intersubjetiva, o "mundo" se revela; nesse processo de desvelamento, são levadas a sério as consequências de se compreender como ser-no-mundo.

A hermenêutica gadameriana tem a pretensão de superação da subjetividade pura e simples, determinante de todos os sentidos, a partir 
da inclusão da experiência hermenêutica no processo de conhecimento; reconhecendo-se a finitude e um mundo já sempre contaminado historicamente por sentidos, põe-se em pauta a necessidade de se discutir uma vez mais a relação entre o sujeito compreendente e os sentidos. Talvez, como sugere a citação a seguir, Gadamer não tenha vislumbrado num primeiro momento todas as potencialidades do seu diálogo, mas esse projeto conseguiu equacionar de forma inovadora as liberdades adquiridas pela modernidade e as limitações existenciais e históricas. Veja:

Com a experiência hermenêutica, com o jogo, com o círculo, Gadamer procurou destronar a absolutização da subjetividade moderna no processo do conhecimento. Destronamento em que o sujeito é jogado e se encontra compreendido numa circularidade do conhecimento; afinal, não podemos perguntar ou querer saber mais sobre o que já não pré-conhecemos, pré-supomos ou intuímos. 0 sujeito não apenas experimenta novas e outras formas de conhecer, mas as experiências porque nunca parte do grau zero de conhecimento. Talvez Gadamer tenha subestimado a importância da subjetividade moderna. Pelo diálogo é possível ressaltar, mais especificamente, a força do processo relacional do saber filosófico. No diálogo, o sujeito deve ser visto e assumido em sua relação à alteridade, com a liberdade que conquistou na modernidade, em meio aos condicionamentos existenciais e históricos.

O modo próprio de ser da linguagem, da hermenêutica filosófica, pode ser representado pelo jogo, pelo círculo hermenêutico, mas possui seu modo mais apropriado de realizar-se no diálogo. Gadamer apenas indicou isso ao final de VMI [Verdade e Método I], sem aprofundar, tanto que, nas últimas páginas dessa obra, volta a falar do jogo e não do diálogo. O diálogo mostra melhor a dimensão do processo relacional do saber, enquanto jogo e o círculo hermenêutico ressaltam a subjetividade afetada daquele que joga ou compreende compreendendo-se circularmente (ROHDEN, 2002, p. 180-181).

Esse processo dialógico pressupõe que tudo que se pode compreender "é sempre linguagem e que todo encontro com o 'mundo', mesmo com as coisas, na sua imediatidade se revela como um encontro linguístico" (BIAGIONI, 1983, p. 33). Ademais, é inerente ao diálogo afirmar que "jamais acontece o dar-se das pessoas, das coisas, enfim do 
"mundo" fora da linguagem" (BIAGIONI, 1983, p. 33). E o como desse processo dialógico ocorre num esquema de pergunta e resposta.

Pois bem. Na experiência hermenêutica de compreender um texto, a aplicação significa fazer o texto falar novamente, mas a partir do horizonte do intérprete: tem-se um Tu falando com o intérprete. Gadamer relata três relações possíveis entre Eu e Tu, a saber: na primeira, o Eu trata o Tu como objeto, sendo este subsumido a categorias de comportamento que o tornam previsível. Nesta relação, vê-se a preponderância do método, em que o intérprete acredita ingenuamente na objetividade, isto é, o intérprete assume a posição de um observador ideal. A segunda relação, por sua vez, reconhece o outro como uma pessoa, mas afirma conhecer o outro exclusivamente a partir de seu ponto de vista, frisando, inclusive, a possibilidade de o Eu conhecer o outro melhor do que ele próprio se conhece. Neste caso, o intérprete transcende seu próprio condicionamento histórico e afirma ser capaz de compreender o autor melhor do que ele compreendia a si próprio (relembre-se aqui de Schleiermacher e Dilthey). Na terceira relação, finalmente, o Eu escuta o outro e está aberto a suas reivindicações. Isto significa, pois, reconhecer que é preciso deixar que o Tu possa realmente dizer algo. Nesta relação, enfim, vê-se uma relação apropriada com o texto. 0 intérprete, assim, deve escutar o que o texto pode dizer enquanto parte da tradição: o intérprete deve se abrir para uma nova experiência (SCHMIDT, p. 2014, p. 161-162).

Partindo dessa terceira distinção entre Eu e Tu e crendo ser necessária certa deferência em relação ao Outro principalmente diante das limitações existenciais de cada um e da morte do sujeito assujeitador ${ }^{17}$, nota-se a seguir a relevância da lógica da pergunta e da resposta; isto porque ao passo que se reconhece no Tu alguém capaz de dizer algo, dá-se a real dimensão à experiência hermenêutica, experiência esta que sempre almeja compreender:

A estreita relação que se mostra entre perguntar e compreender é a única que dá sua real dimensão à experiência hermenêutica. Aquele que quer compreender pode deixar em suspenso a verdade do que tem em mente. Ele pode ter retrocedido desde a intenção imediata da coisa à intenção de sentido como tal, e considerar esta não como verdadeira, mas simplesmente como algo com sentido, de maneira que a possibilidade de verdade fique 
em suspenso. Esse pôr-em suspenso é a verdadeira essência original do perguntar. Perguntar permite sempre ver as possibilidades que ficam em suspenso. Por isso, se é possível compreender uma opinião à margem do próprio opinar, não é possível compreender a questionabilidade desligando-nos de um verdadeiro questionar. Compreender a questionabilidade de algo já é sempre perguntar. Para perguntar não pode haver um comportamento em potencial, servindo apenas como teste comprobatório, isso porque perguntar não é pôr mas experimentar possibilidades. Aqui, a partir da essência do perguntar torna-se claro o que o diálogo platônico demonstra na sua realização fática. Quem quiser pensar deve perguntar. Quando alguém diz "aqui caberia uma pergunta", isto já é uma verdadeira pergunta, disfarçada pela prudência e cortesia (GADAMER, 2014, p. 488-489).

Em verdade, a compreensão de cada um sempre traz a marca da tradição - que se dá como antecipação de sentido. Entretanto, é necessário notar que tal antecipação não se dará como mera ação da pura subjetividade, mas, antes, surgirá da comunidade dialógica que une cada homem com a tradição. Dessa forma, o verdadeiro locus hermenêutico é, pois, o da posição entre o desconhecido e o familiar na tradição (BIAGIONI, 1983, p. 42). Ademais, esclarecendo o diálogo com a tradição e relacionando-o à lógica da pergunta e resposta, veja:

A reconstrução da pergunta à qual responde um determinado texto não pode ser tomada, evidentemente, como uma mera realização da metodologia histórica. Ao contrário o que vem por primeiro é a pergunta que o texto nos coloca, sermos atingidos pela palavra da tradição. Assim, na verdade, a relação entre pergunta e resposta se inverteu. 0 que é transmitido nos fala - o texto, a obra, o vestígio - impõe, ele próprio, uma pergunta, colocando nossa opinião no aberto. Para poder responder a essa pergunta que nos é colocada, nós, os interrogados, temos que começar, por nossa vez, a perguntar. Para poder responder a essa pergunta que nos é colocada, nós, os interrogados, temos que começar, por nossa vez, a perguntar. Procuramos reconstruir a pergunta a que responderia aquilo que é transmitido. A reconstrução da pergunta a que o texto deve responder está, ela mesma, situada dentro de uma interrogação com a qual procuramos responder à pergunta que a tradição nos coloca. Uma pergunta reconstruída não pode nunca permanecer em seu horizonte originário. 0 horizonte histórico descrito na construção não é verdadeiramente um horizonte englobante. Encontra-se, antes, ele mesmo, abarcado pelo horizonte que nos engloba a nós que perguntamos e somos atingidos pela palavra da tradição (GADAMER, 2014, p. 487-488). 
A hermenêutica filosófica há de apresentar uma postura de abertura autêntica para o diálogo, sempre com a possibilidade real de se abrir para a revisão dos próprios preconceitos. Dito isso, o próprio Gadamer ressalta que para que haja um diálogo autêntico tudo precisa se afinar: a hermenêutica filosófica não dá azo para o autoritarismo do subjetivismo; antes, impõe uma relação autêntica entre sujeito interpretante e a linguagem, que jamais é alheia à intersubjetividade. Veja:

Para que um diálogo aconteça, tudo precisa se afinar. Quando o companheiro de diálogo não nos acompanha e não vai além de sua resposta, mas só tem em vista, por exemplo, com que meios de contra-argumentação ele pode limitar o que foi dito ou mesmo com que argumentações lógicas ele pode estabelecer uma refutação, não há diálogo algum- um diálogo frutífero é um diálogo no qual oferecer e acolher, acolher e oferecer conduzem, por fim, a algo que se mostra como um sítio comum com o qual estamos familiarizados e no qual podemos nos movimentar uns com os outros (2012, p. 38).

Ou ainda, Chris Lawn diz o seguinte sobre a relação com o Outro no diálogo: "para Gadamer o entendimento é a acomodação do Outro [...] o ponto não é obscurecer e abolir o horizonte do passado (concebido como outro), mas mostrar como aquele horizonte foi adotado e expandido no presente" (2007, p. 96). Têm-se, pois, mais uma vez a preponderância de uma hermenêutica da escuta.

Com efeito, se a hermenêutica filosófica pressupõe o fato de que sempre exista um processo dialógico na relação do sujeito com o mundo, isto é, em qualquer fenômeno de compreensão (sem desconsiderar que a compreensão faz parte do modo de ser próprio do Dasein), a saída histórica de Gadamer é adequada: isto porque nunca pretende responder em absoluto; antes, pretende responder em função de uma história que inevitavelmente é conhecida exclusivamente pela linguagem e, necessariamente, é intersubjetiva: a linguagem é intersubjetiva. Nesse processo dialógico, sempre provisório, vê-se a mais autêntica contemplação de desvelamento do ser. Pois, a linguagem é a casa do ser ${ }^{18}$ : se a linguagem é a casa do ser e se se estiver de acordo quanto a sua necessária intersubjetividade, vê-se que uma mudança de postura do sujeito em relação ao mundo se manifesta como o melhor meio de acesso 
à verdade, isto porque não existe algo como meu mundo, mas somente um mundo que é atravessado por uma constituição de sentido histórica e intersubjetiva. A esse respeito, veja:

[E]m qualquer processo dialógico - e mesmo na tentativa de uma redução solipsista da subjetividade - não pode existir um polo, "sujeito" ou "objeto", nem mesmo a própria consciência, nem o espírito absoluto que se pretenda colocar-se em uma esfera meta-histórica ou a-histórica. As situações humanas vivenciais são sempre realizadas como dialogais, onde sujeito compreendente e objeto compreendido não se encontram jamais fora da história à qual pertencem. 0 diálogo, a experiência linguística é histórica. E a partir da mais simples e quotidiana efetivação da linguagem revela-se um conteúdo de um "mundo", de história e se constata a impossibilidade de desvincular-se, do "ser conhecido", a linguagem. Aliás, a palavra dá à coisa falada uma certa conclusividade e finitude: é a "forma-imagem" da realidade, à maneira do Heidegger afirma na "Carta sobre o Humanismo": "a linguagem é a casa do ser". Nela se re-vela ou se oculta a verdade (...) Na linguagem, portanto, a verdade, o "mundo" se revelam e deles se pode usufruir (BIAGIONI, 1983, p. 34).

De fato, Gadamer desenvolve uma lógica hermenêutica de pergunta e resposta, a qual entende a compreensão como participação num significado, numa tradição, enfim, numa conversação (GRONDIN, 1999, p. 198). Além disso, a compreensão sempre se manifesta como um evento histórico, dialético e linguístico, seja nas ciências naturais, seja nas ciências humanas. Dessa forma, a hermenêutica é a ontologia e a fenomenologia da compreensão, pelo que não se pode mais apresentar a compreensão de modo tradicional como um ato da subjetividade humana, mas, sim, como o modo essencial que o Dasein tem de estar-no-mundo. Com efeito, as chaves para a compreensão não são a manipulação e o controle, mas, sim, a experiência. Também não é chave da compreensão a metodologia, mas, sim, a dialética: o objetivo da hermenêutica não é avançar com regras para uma compreensão objetivamente válida, mas conceber a própria compreensão de um modo tão lato quanto possível (PALMER, 2011, p. 216). 


\section{CONSIDERAÇõES FINAIS}

É inviável a exposição exaustiva de toda a filosofia que influenciou o pensamento gadameriano na constituição de sua hermenêutica filosófica. Contudo, o panorama dos autores apresentados permite reconstruir ao menos de forma incipiente o que teve especial relevância para a constituição da hermenêutica filosófica de Gadamer: Schleiermacher foi decisivo na constituição do pensamento de Gadamer por ser o primeiro a apresentar a hermenêutica de forma universal, sem as amarras de uma disciplina específica de interpretação jurídica, bíblica ou filológica. Dilthey, por sua vez, contribuiu para o alargamento do sentido da vida e da história na hermenêutica. Heidegger, finalmente, contribui a partir da elaboração da sua hermenêutica da faticidade, da analítica existência e por colocar a linguagem como meio de desvelamento do ser, sem o que não seria possível uma hermenêutica essencialmente pautada no diálogo, como é a hermenêutica filosófica de Gadamer.

A partir da contribuição dos referidos autores, mas sem se limitar a eles, Gadamer elabora o que vai chamar de hermenêutica filosófica, tese que promove um verdadeiro hermeneutic turn de modo a pôr como tarefa da própria filosofia a compreensão da historicidade do mundo vivido. Com isso, o filósofo inunda de pragmática e intersubjetividade a própria compreensão, pois assim que a compreensão da historicidade do mundo vivido se dá mediante compreensão da linguagem, coloca-se a compreensão sob controle de uma comunidade de sentido compartilhado, que se testará a correção das interpretações mediante o jogo de pergunta e resposta, a ser realizado num diálogo autêntico com a tradição.

Ademais, as características intersubjetiva e pragmática da hermenêutica filosófica a põe em posição diametralmente oposta ao método, de forma que se pôde pincelar argumentos para um raciocínio contra-metódico no direito - ao menos do uso do método no sentido proposto pela hermenêutica jurídica tradicional.

Por derradeiro, justifica-se como contributo deste artigo para a comunidade acadêmica o fato de que permanece em aberto a possibilidade de se explorar de forma mais profunda e profícua uma hermenêutica jurídica exclusivamente a partir de Gadamer - como fizeram autores 


\section{como Hernández-Largo -, ou ainda investigar a elaboração de uma teoria da decisão judicial propriamente dita a partir das reflexões filosóficas propostas neste artigo, para inundar de filosofia a prática do direito.}

\section{NOTA}

1 Embora não sejam poucos os autores que associam hermenêutica ao deus grego Hermes, seguindo Jean Grondin, soou prudente deixá-la de lado para a redação deste trabalho. Assim manifestou-se Grondin: "A atividade mediadora do processo hermenêutico conduziu, já na antiguidade, a que a família verbal em torno de 'hermeénêus' e da 'hermèneutiké' fosse relacionada etimologicamente com o deus mediador Hermes. A conexão é, sem dúvida, demasiado patente para ser verdadeira. Por isso, na filologia mais recente, em quase toda a parte, foi encarada com razoável ceticismo. No entanto, nenhuma explicação etimológica conseguiu, até agora, impor-se universalmente, de modo que a questão sobre a origem do campo verbal de 'hermeènêuein' deve, aqui, continuar inconclusa" (1999, p. 55).

2 É verdade que Richard Palmer apresenta seis conceituações sobre hermenêutica em seu livro, mas o breve espaço deste trabalho não permite explorá-las a contento. Ademais, os estudos do autor do presente trabalho tem se centrado na obra de Hans-Georg Gadamer, que, como o texto sugere, há de ser a última conceituação na qual desemboca as demais (a quinta). No entanto, embora a narrativa possa sugerir uma espécie de teleologia, não se tem a pretensão ignorar a relevância de cada contribuição aqui referida. Antes, acredita-se que cada conceituação tem o seu papel na história. Afinal, seguindo os passos do próprio Gadamer, seria temerário negar a temporalidade e usar o presente como padrão de correção do passado (ver: PALMER, 2011, p. 43-54).

3 É verdade que o círculo hermenêutico não foi originariamente concebido por Schleiermacher, mas, como apresenta Gadamer a seguir, por ele é essencialmente ressignificado: “Quando Schleiermacher reconhece como um traço essencial do compreender o fato de que o sentido do peculiar só pode resultar do contexto e, em última análise, do todo, está seguindo a Friedrich Ast e toda a tradição hermenêutico-retórica. Esse postulado pode ser aplicado naturalmente para a compreensão gramatical de toda e qualquer frase, para sua integração no contexto do todo de uma obra literária e até mesmo para o todo da literatura ou seu respectivo gênero literário - mas Schleiermacher aplica-o também à compreensão psicológica, que deve compreender toda formulação do pensamento como um momento vital do contexto atual deste homem" (GADAMER, 2014, p. 261).

4 Reiteradamente se retornará nesse termo "pré-compreensão"; no entanto, salienta-se que poderão ser utilizados, para demonstrar o mesmo conceito, os termos “pré-juízos" ou "preconceitos", ambos também representando essa condição de possibilidade da própria compreensão.

5 Eventualmente poderá ser utilizado o termo "ciências humanas" ou "ciências históricas" com pretensão de expressar essa mesma ideia, de ciências não-naturais.

6 Em outras palavras, o que divide as ciências humanas e as ciências naturais é o seu objetivo: no caso das ciências naturais o objetivo é explicação, mas essa explicação não serve às ciências humanas: o que é necessário aqui é entendimento, ao invés de uma mera descrição empírica direta e explicação (LAWN, 2006, p. 74-75).

7 Em sentido análogo, ver: MARÍAS, Julian. História da Filosofia. Prólogo de Xavier Zubiri. Epílogo de José Ortega y Gasset. Tradução Cláudia Berliner. Revisão Franklin Leopoldo e Silva. São Paulo: Martins Fontes, 2004, pgs, 419-426.

8 É na consciência histórica que se percebe o fluxo do tempo: a temporalidade está contida na vida. Na memória, tem-se o passado que não pode ser mudado. No presente, nota-se o passar constante do presente, de forma que o presente nunca é. Finalmente, é possível notar que no futuro, é possível ser ativo e livre (SCHMIDT, 2014, p. 61).

9 Ou: "La fenomneología se presenta como uma reflexíon filosófica que quiere fundamentar firmemente la objetividad del saber mediante un método, cuya principal regla es dejar que "las cosas mismas" se hagan patentes en su contenido esencial, a través de uma mirada intituitiva que 
haga presente las coisas tal como se dan inmediatamente para el que las vive y poniendo entre paréntesis el juicio sobre la validez de los presupuestos, opiniones o interpretaciones acerca de ellas"(MAZA, 2015, 123)

10 Paradigma filosófico imperante antes do giro linguístico-pragmático.

11 Nesse sentido, saliente-se que o termo "mundo" em Heidegger não se identifica com meio ambiente. Antes, este termo está mais próximo daquilo a que se poderia conceber como mundo pessoal. Assim, seria um equívoco conceber o mundo separado da pessoa, pois pressupõem a separação sujeito-objeto que aparece no interior do contexto relacional a que se chama de mundo. Dessa forma, o mundo é anterior a qualquer separação da pessoa e do mundo num sentido objetivo (PALMER, 2011, p. 136-137)

12 Foi em Dilthey que Heidegger encontrou, estudou e foi influenciado pela questão da temporalidade, da vida e da historicidade do saber. Assim, a virada promovida por Heidegger só foi possível porque recepcionou principalmente a temporalidade e a historicidade a partir da fenomenologia husserliana (ROHDEN, 2002, p. 66).

13 De fato, em Heidegger a hermenêutica "[p]ela sua procedência da fenomenologia, ela representa uma crítica aos traços modernos da teoria do conhecimento, como a questão da subjetividade, 0 fundamento, a razão compreendida como absoluta. Mas, de outro lado, traria uma contribuição não apenas de complementaridade na questão do conhecimento, mas também uma nova forma de expor certos pressupostos do conhecimento tal como era apresentado na modernidade" (STEIN, 2014, p. 206-207)

14 Contra a pretensão de um fundamento último de verdade, Heidegger vai opor uma ideia de verdade que deve reconhecer radicalmente a finitude: "A concepção de que existe uma verdadeira absoluta, brotaria, pois, de uma repressão ou esquecimento da própria temporalidade. Em vez de perseguir o fantasma de um último fundamento, Heidegger recomendava estabelecermo-nos radicalmente ao nível da finitude, elaborando a própria estrutura preconceituosa como estrutura positiva e ontológica da compreensão, para percebermos as nossas próprias possibilidades, a partir da nossa situação existencial" (GRONDIN, 2003, p. 180).

15 Para conferir a abordagem do próprio Savigny, verificar: SAVIGNY, Friedrich Karl von.[1840-1849] Sistema del Derecho Romano Actual. Tomo I. Madrid: Gongora y Compañia Eds, 1878. pp. 149-151.

16 Carlos Maximiliano, à sua moda, foi um grande propagador dos métodos de interpretação do direito no Brasil na sua clássica obra "Hermenêutica e aplicação do Direito".

17 Indivíduo que se crê portador dos sentidos; portanto, uma negação da intersubjetividade proposta por Gadamer.

18 Compete à linguagem revelar o ente em sua verdade e exprimi-la na palavra. No entanto, o que se revela nunca é só um ente: no dizer o ente transcendemos o ente na direção do ser. Então, é por meio da palavra que se realiza o evento do desvelamento. Assim, é na força da palavra que o homem, ser histórico, vem ao ser. Heidegger chama esse evento de relação hermenêutica entre o homem e o ser. A consideração dessa problemática significa, em Heidegger, o pôr o alicerce para a construção de um novo paradigma: a ontologia hermenêutica é um retorno ao evento de desvelamento que é também, ao mesmo tempo, ocultamento (essa é a aporia originária do ser enquanto evento de desvelamento) (Entbergen) e ocultamento (Verbergen) enquanto temporalização do ser (OLIVEIRA, 2006, p. 213).

\title{
REFERÊNCIAS
}

\author{
BARROSO, Luís Roberto. Curso de direito constitucional contemporâneo: \\ os conceitos fundamentais e a construção do novo modelo. 4. ed. São Paulo: \\ Saraiva, 2013.
}


BIAGIONI, João. A ontologia hermenêutica de H. G. Gadamer: reflexões e perspectivas sobre a 3 a parte de "Verdade e Método". Uberlândia: Universidade Federal de Uberlândia, 1983.

BONAVIDES, Paulo. Curso de direito constitucional. 15. ed. Malheiros: São Paulo, 2004.

BRAIDA, Celso Reni. Apresentação. In: SCHLEIERMACHER, Friedrich D.E. Hermenêutica - Arte e técnica da interpretação. Tradução e Apresentação de Celso Reni Braida. Petrópolis, RJ: Vozes, 1999.

CATOGGIO, Leandro. La interpretación gadameriana de Dilthey en torno al estatuto transcendental de la hermenêutica. Areté Revista de Filosofía, v. XXIV, n. 2, 2012, p. 289-308.

DILTHEY, Wilhelm. 0 surgimento da hermenêutica. Numen: Revista de Estudos e Pesquisa da Religião, Juiz de Fora, v. 2, n. 1, p. 11-32, 1999.

GADAMER, Hermenêutica em retrospectiva. Tradução de Marco Antônio Casanova. 2. ed. Petrópolis, RJ: Vozes, 2012.

Verdade e método. Tradução de Flávio Paulo Meurer. 14. ed. Petrópolis, RJ: Vozes, 2014.

GRAU, Eros Roberto. Por que tenho medo dos juízes: a interpretação/ aplicação do direito e os princípios. 6. ed. refundida do ensaio e discurso sobre a interpretação/aplicação do direito. São Paulo: Editora Malheiros, 2014.

GRONDIN, Jean. Introdução à hermenêutica filosófica. Tradução de Benno Dischinger. São Leopoldo: Editora UNISINOS, 1999.

HEIDEGGER, Martin. Carta sobre o humanismo. 2. ed. rev. Tradução de Rubens Eduardo Frias. São Paulo: Centauro, 2005.

Ser e tempo. Tradução revisada e apresentação de Marcia Sá Cavalcante Schuback; posfácio de Emmanuel Carneiro Leão. 9. ed. Petrópolis, RJ: Vozes; Bragança Paulista, SP: Editoria Universitária São Francisco, 2014. 
LARGO, Antonio Osuna Hernández. Hermenéutica jurídica em torno a la hermenêutica de Hans-Georg Gadamer. Valladolid: Secretariado de Publicaciones Universidad de Valladolid, 1992.

LAWN, Chris. Compreender Gadamer. Petrópolis, RJ: Vozes, 2007.

LOZADA, María Del Mar Esguerra. Comprensión y autocomprensión en la hermenêutica de Gadamer, y algunas pespectivas para el humanismo. Universitas Philosophica, Bogota - Colombia, 31 (63), p. 97-117, ISSN 0120-5323.

MARÍAS, Julian. História da filosofia. Prólogo de Xavier Zubiri. Epílogo de José Ortega y Gasset. Tradução de Cláudia Berliner. Revisão de Franklin Leopoldo e Silva. São Paulo: Martins Fontes, 2004.

MAZA, Luis Mariano de la. Fundamentos de la filosofia hermenêutica: Heidegger y Gadamer. Teología y Vida, v. XLVI, p. 122-138, 2005.

MISSAGIA, Juliana. A hermenêutica em Heidegger e Gadamer: algumas confluências e divergências. Griot - Revista de Filosofia, Amargosa - Bahia, v. 6, n. 2, p. 1-13, dezembro 2012.

OLIVEIRA, Manfredo Araújo de. Reviravolta linguístico-pragmática na filosofia contemporânea. 3. ed. São Paulo: Edições Loyola, 2006.

PALMER, Richard e. Hermenêutica. Rio de Janeiro: Edições 70, 2011.

PEREIRA, Rodolfo Viana. Hermenêutica filosófica e constitucional. 2. ed. Belo Horizonte: Del Rey, 2006.

ROHDEN, Luiz. Hermenêutica filosófica: Entre a linguagem da experiência e a experiência da linguagem. São Leopoldo, RS: Editora Unisinos, 2002.

RUEDELL, Aloísio. Gadamer e a recepção da hermenêutica de Friedrich Schleiermacher: uma discussão sobre a interpretação psicológica. Veritas, Porto Alegre - Rio Grande do Sul, v. 57, n. 3, p. 74-85, set-dez. 2012.

SAVIGNY, Friedrich Karl. Sistema del Derecho Romano Actual. Madrid: Gongora y Compañia Eds, t. 1, 1878.

SCHIMDT, Lawrence K. Hermenêutica. Petrópolis, RJ: Editora Vozes, 2012. 
STRECK, Lenio Luiz. Verdade e Consenso: constituição, hermenêutica e teorias discursivas. 5. ed. rev. São Paulo: Saraiva, 2014.

O que é isto - decido conforme minha consciência? - 4. ed. rev. Porto Alegre: Livraria do Advogado Editora, 2013.

STEIN, Ernildo. Gadamer e a consumação da Hermenêutica. Problemata: Revista Internacional de Filosofia, v. 5, n. 1, p. 204-226, 2014. ISSN 2236-8612.

Pensar e errar: um ajuste com Heidegger. Ijuí: Editora Unijuí, 2011 (Coleção filosofia; 37).

Recebido em: 02-06-2017

Aprovado em: 13-12-2018

\section{Fernando de Brito Alves}

Doutor em Direito pela Instituição Toledo de Ensino - ITE / Bauru-SP. Mestre em Ciência Jurídica pela Universidade Estadual do Norte do Paraná - UENP. Graduado em Filosofia pela Universidade do Sagrado Coração e graduado em Direito pela Faculdade Estadual de Direito do Norte Pioneiro, é especialista em "História e historiografia: sociedade e cultura" pela Faculdade Estadual de Filosofia, Ciências e Letras de Jacarezinho. Advogado.

E-mail: fernandobrito@uenp.edu.br

\section{Guilherme Fonseca de Oliveira}

Mestre em Ciência Jurídica pela Universidade Estadual do Norte do Paraná UENP (Bolsista CAPES). Especialista em "Direito Constitucional Contemporâneo" pelo Instituto de Direito Constitucional e Cidadania - IDCC. Graduado em Direito pela Universidade Estadual de Londrina - UEL. Especialista em "EAD e Novas Tecnologias" pela Faculdade Educacional da Lapa - FAEL. Cursa Graduação em Filosofia na Universidade Estadual de Londrina - UEL. Atua como "Webtutor" na Faculdade Educacional da Lapa - FAEL. É advogado com inscrição na OAB/ Pr. sob n‥ 69.422 .

E-mail: guilherme.advc@hotmail.com

Universidade Estadual do Norte do Paraná - UENP

Campos de Jacarezinho - Centro de Ciências Sociais e Aplicadas (CCSA)

Av. Manoel Ribas, n. 711, Centro, 86400 000. Jacarezinho. Paraná. Brasil. 
